ORIGINAL ARTICLE

\title{
Tovomita nebulosa (Clusiaceae), a new species from Cerro de la Neblina, Venezuela
}

\author{
Lucas C. MARINHO ${ }^{1,2 *}$, Manuel LUJÁN³ ${ }^{3}$ Pedro FIASCHI ${ }^{4}$, André M. AMORIM 5,6 \\ Universidade Federal do Maranhão, Centro de Ciências Biológicas e da Saúde, Departamento de Biologia, Av. dos Portugueses 1966, Bacanga 65080-805, \\ São Luís, Maranhão, Brazil \\ 2 Universidade Estadual de Feira de Santana, Programa de Pós-Graduação em Botânica, Av. Transnordestina s/n, Novo Horizonte 44036-900, \\ Feira de Santana, Bahia, Brazil \\ 3 California Academy of Sciences, 55 Music Concourse Drive, Golden Gate Park, San Francisco, California 94118, USA \\ ${ }^{4}$ Universidade Federal de Santa Catarina, Centro de Ciências Biológicas, Departamento de Botânica, Trindade 88040-900, Florianópolis, Santa Catarina, Brazil \\ 5 Universidade Estadual de Santa Cruz, Departamento de Ciências Biológicas, Km 25 Rodovia Ilhéus-Itabuna 45662-900, Ilhéus, Bahia, Brazil \\ ${ }^{6}$ Centro de Pesquisas do Cacau, Herbário CEPEC, Km 16 Rodovia Itabuna-Ilhéus 45650-970, Itabuna, Bahia, Brazil \\ * Corresponding author: Icmarinho1@gmail.com; (D) https://orcid.org/0000-0003-1263-3414
}

\section{ABSTRACT}

Although the number of recently described Tovomita species is relatively high, much more remains to be done, given that each new survey of representative Amazonian collections reveals many potentially undescribed taxa. In the treatment for Tovomita published in Flora of the Venezuelan Guayana, at least six distinct morphotypes did not match any previously described species. Here we recognize morphotype " $\mathrm{D}$ " as a new endemic species from Cerro de la Neblina. Additionally, we provide an identification key to the Tovomita species in Venezuela.

KEYWORDS: Amazon Forest, clusioid clade, Malpighiales, Pico da Neblina, South America

\section{Tovomita nebulosa (Clusiaceae), una nueva especie del Cerro de la Neblina, Venezuela}

\section{RESÚMEN}

A pesar del relativo alto número de especies nuevas de Tovomita descritas en los últimos años, aún queda mucho por hacer, ya que en cada nueva investigación de colecciones amazónicas surgen taxa aún no descritos. En el tratamiento de Tovomita publicado en la Flora de la Guayana Venezolana, al menos seis morfotipos distintos no coincidían con ninguna de las especies descritas hasta el momento. Aquí reconocemos el morfotipo "D" como una nueva especie endémica del Cerro de la Neblina. Además, proporcionamos una clave de identificación para las especies venezolanas de Tovomita.

Palabras-Clave: Amazonia, clado clusioide, Malpighiales, Pico da Neblina, Sudamérica

\section{INTRODUCTION}

Recent estimates indicate there are around 16,000 vascular plant species reported for Venezuela, although many more taxa are yet to be described, particularly from the country's southern region (Huber 2008). The Guiana Shield has largely been considered one of the most biologically fascinating regions, given its physiographic complexity and high levels of endemism. Approximately 10,000 plant species are known from Venezuelan Guayana and about $40 \%$ of the species are restricted to the shield (Berry et al. 1995). Within the Guayana Shield, Cerro de la Neblina is the tallest mountain (3014 $\mathrm{m})$ and has the highest level of endemism, with at least 104 endemic plant species (Riina et al. 2019).
There are 20 recorded species of Tovomita in Venezuela (see Appendix 1 in Marinho 2019). Although the number of recently described Tovomita species is relatively high, much more remains to be done, given that each new investigation of representative Amazonian collections reveals many potentially undescribed taxa (Frazáo and Lohmann 2018; Toledo and Souza 2018; Huamantupa-Chuquimaco et al. 2019; Melo et al. 2019), including the Venezuelan Amazon (Cabral et al. 2016, 2018; Marinho et al. 2016a, 2019; Nascimento Jr. et al. 2019). In the treatment of Tovomita in the Flora of the Venezuelan Guayana, Cuello (1998) defined at least six distinct morphotypes that did not match any previously described species. Subsequently, morphotype "A" was described as T. auriculata Cuello and morphotype "B" was 
described as T. foldatsii Cuello (Cuello 1999). Marinho (2019) identified morphotype "E" as T. acutiflora M.S. Barros \& G. Mariz and segregated morphotype "F" into two new species: T. clarkii Pipoly ex. L. Marinho \& Gahagen (Marinho et al. 2016a), and T. nervosa L. Marinho (Marinho et al. 2019). Unfortunately, morphotype "C" was not located, but most likely corresponds to an undescribed species.

Here we recognize morphotype " $D$ " as a new endemic species from Cerro de la Neblina. Additionally, we provide an identification key to the species of Tovomita in Venezuela.

\section{MATERIAL AND METHODS}

The description is based on specimens at NY and VEN (abbreviations according to Thiers 2020). Leaf terminology follows Ellis et al. (2009) and flower terminology follows Radford et al. (1974). The conservation status of the new species was accessed according to IUCN (2012) criteria. The species distribution map was produced using the SimpleMappr website (Shorthouse 2010) with subsequent style modifications.

\section{RESULTS}

Tovomita nebulosa L. Marinho \& Luján, sp. nov. Type: Venezuela. Amazonas: Departamento Río Negro, Cerro de La Neblina Camp IV, $15 \mathrm{~km}$ NE of Pico Phelps, north branch of river in canyon, $780 \mathrm{~m}, 0^{\circ} 51^{\prime} \mathrm{N}, 65^{\circ} 57^{\prime} \mathrm{W}, 15-18$ Mar 1984 (bud), R. Liesner 16670 (holotype: NY! barcode NY02859712; isotypes: BRIT image! barcode BRIT554535, MO, US, VEN! no. 327548).

Diagnosis: Tovomita nebulosa is similar to T. tenuiflora Benth. ex Planch. \& Triana by the large number of secondary and intersecondary veins, close and similar to each other, and nigrescent staminate floral buds in sicco, 5-7 mm long, with a cuspidate to slightly rostrate apex. The species can be distinguished by the number of secondary veins $(<23$ pairs $v s$. $>30$ pairs in T. tenuiflora) and number and shape of the filaments (c. 20 , terete $v$ s. c. 50 , filiform-terete).

Description: Small tree, up to c. $3 \mathrm{~m}$ tall, prop roots and exudate not seen. Petioles $0.9-1.3 \mathrm{~cm}$ long, color not seen, smooth, lenticels absent. Leaf blades 4-10 × 2.6-5 cm, dark brown adaxially and light brown abaxially in sicco, black dots absent, subcoriaceous, oblong to obovate, the base decurrent, the apex acute to rounded, sometimes slightly acuminate; exudate canals immersed on both surfaces, visible as thin nigrescent lines abaxially, parallel to the secondary veins. Venation: midvein prominent on both surfaces; secondary veins in $20-23$ pairs, $2.5-3.2 \mathrm{~mm}$ apart, forming a $65^{\circ}-75^{\circ}$ angle to the midvein, prominent on both surfaces, slightly arcuate and connecting near the margin; intersecondary veins present, one or two per intercostal area, similar to the secondary veins, distal course reticulating, $>50 \%$ of the length of subjacent secondary veins; tertiary veins percurrent, sinuous; intramarginal vein present. Staminate inflorescences a lax dichasium with up to 35 flowers, with primary flower; bracts 2, c. $0.8 \mathrm{~mm}$ long, triangular, on the base of the inflorescence. Pedicel 4-9 mm long, color not seen, articulated in the middle in lateral flowers of the dichasia, distal portion of pedicel slightly dilated; bracteoles 2, c. 0.5 $\mathrm{mm}$ long, triangular; bracteoles not calyptrate, lenticels absent. Staminate floral buds 5-7 ×1.5-2 mm, narrowly oblong, apex cuspidate to slightly rostrate, whitish, lenticels absent, nigrescent in sicco. Sepals 2, 5-7 × 2.5-3 mm, oblong to narrowly ovate, apex cuspidate to acuminate, acumen $1.5-2$ mm long, whitish; petals 4 , c. $6.2 \times 1.5 \mathrm{~mm}$, the innermost petal c. $3.5 \times 1 \mathrm{~mm}$, smaller than the others, linear to narrowly oblong, the apex acute to cuspidate, color not seen. Staminate flowers with c. 20 stamens, arranged in two whorls, 3.3-4.8 $\mathrm{mm}$ long, slightly angular, heterodynamous, the central ones larger than the marginal ones; filaments terete, color not seen; anthers $0.3-0.5 \mathrm{~mm}$ long, with the same caliber as the filaments, connective not exceeding the thecae; pistillode c. $0.3 \mathrm{~mm}$ long, conical, angular, rudimentary stigmas 4 , amorphous. Pistillate inflorescences, flowers and fruits not seen (Figure 1).

Etymology: The specific epithet refers to the adjective nebulous, which means vague or unclear, in reference to the long period of over 20 years during which this species has been known under the informal name "Tovomita sp. D" (see Cuello 1998). The epithet is also related to the type locality, Cerro de la Neblina. Both "nebulous" and "neblina" have the same origin and derive from the Latin word nebulosus, which means clouded or cloudy (Stern 1992).

Occurrence, habitat and conservation status: Tovomita nebulosa is presumably endemic to Amazonas State, Venezuela, near the border of Amazonas State, Brazil (Figure 2). The only known specimen of this taxon was collected in Cerro de la Neblina (Pico da Neblina, in Portuguese). Although this area is permanently preserved and part of Pico da Neblina National Park, a Brazilian conservation unit, and Serranía de la Neblina National Park, a Venezuelan conservation unit, we assessed the conservation status of the species as Data Deficient (DD), as the species is so far known from a single collection.

\section{DISCUSSION}

The arrangement and quantity of secondary and intersecondary veins, as well as floral bud shape (Barros and Mariz 1982; Marinho 2018), have typically been used as important characters to identify Tovomita species (Vesque 1893; Engler 1923; Cuello 1998; Marinho et al. 2016b). Thus, new taxa can be recognized even when specimens do not bear open flowers. As observed in T. tenuiflora Benth. ex Planch. \& Triana and T. carinata Eyma, the floral buds of T. nebulosa become 


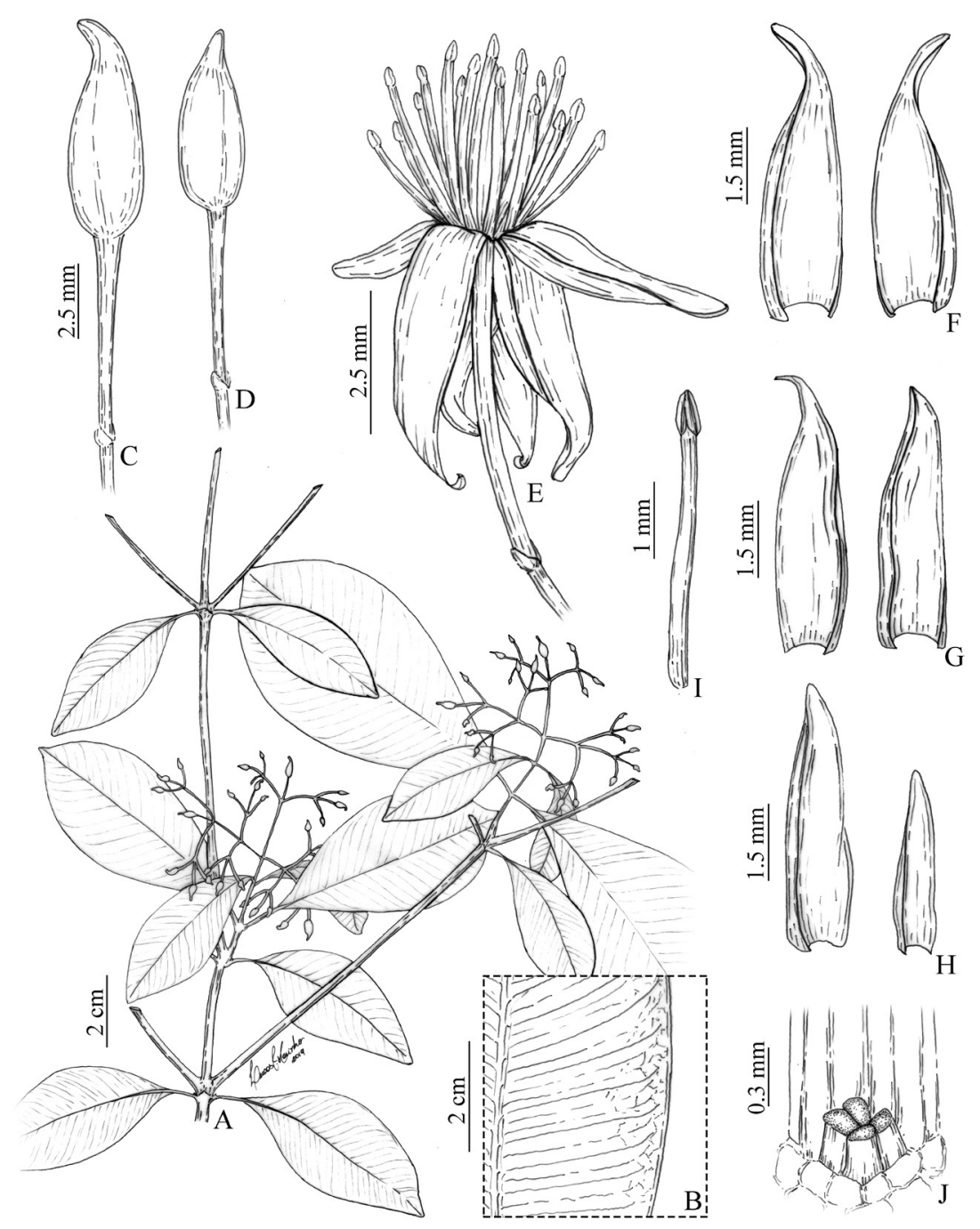

Figure 1. Staminate specimen of Tovomita nebulosa L. Marinho \& Luján: (a) Branch with staminate floral buds; (b) Detail of the abaxial leaf surface; (c) Mature floral bud; (d) Immature floral bud; (e) Staminate flower representation inferred from closed floral bud; (f) Sepals, adaxial view; (g) Outer petals, adaxial view; (h) Inner petals, adaxial view; (i) Stamen, adaxial view; (j) Detail of the pistillode, some stamens removed. Drawing from the type by L.C. Marinho.

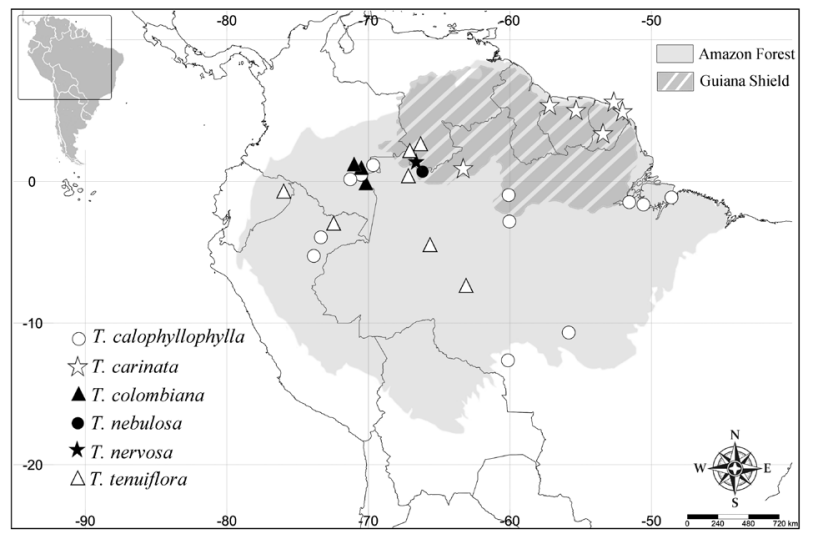

Figure 2. Distribution map of Tovomita nebulosa and morphologically similar Amazonian species: T. calophyllophylla, T. carinata, T. colombiana, T. nervosa, and T. tenuiflora. nigrescent in sicco. Useful features to distinguish T. nebulosa from T. carinata and T. tenuiflora are listed in Table 1.

Although the specimen used here to describe Tovomita nebulosa bears few floral buds, the combination of observable characters (i.e., > 20 pairs secondary veins, staminate floral buds with a cuspidate to slightly rostrate apex, and c. 20 terete stamens) is not found in any other species in the genus. Tovomita nebulosa shares with T. calophyllophylla García-Villacorta \& Hammel the presence of $>20$ pairs of secondary veins that are almost indistinguishable from the intersecondary ones. From this species, T. nebulosa can be distinguished by the smooth petiole ( $v$ s. longitudinally striated in T. calophyllophylla) and narrowly oblong floral bud with a cuspidate to slightly rostrate apex (vs. spherical with rounded apex in T. calophyllophylla). 
Table 1. Comparison among Tovomita nebulosa sp. nov. and five morphologically similar species.

\begin{tabular}{|c|c|c|c|c|c|c|}
\hline & T. nebulosa & T. calophyllophylla & T. carinata & T. colombiana & T. stylosa & T. tenuiflora \\
\hline $\begin{array}{l}\text { Number of secondary } \\
\text { veins }\end{array}$ & $20-23$ pairs & 25 - 50 pairs & $17-20$ pairs & $11-15$ pairs & $8-9$ pairs & c. 35 pairs \\
\hline $\begin{array}{l}\text { Staminate floral buds } \\
\text { (apex) }\end{array}$ & $\begin{array}{l}\text { Cuspidate to slightly } \\
\text { rostrate }\end{array}$ & Rounded & Rounded to apiculate & Rounded & $\begin{array}{l}\text { Acute to } \\
\text { cuspidate }\end{array}$ & Acute \\
\hline $\begin{array}{l}\text { Staminate floral bud } \\
\text { length (mm long) }\end{array}$ & $5-7$ & $4-6$ & $3-5.5$ & $5-6$ & $8.5-11$ & $5-7$ \\
\hline Stamen number & c. 20 & $40-50$ & $26-34$ & c. 45 & $45-50$ & c. 50 \\
\hline Filaments (shape) & Terete & $\begin{array}{l}\text { Dorsiventrally } \\
\text { compressed }\end{array}$ & Terete & Terete & Filiform-terete & Filiform-terete \\
\hline Anther length (mm long) & $0.3-0.5$ & $0.8-1$ & $0.2-0.3$ & $0.3-0.4$ & $0.4-0.5$ & $0.2-0.3$ \\
\hline Carpel number & 4 & 5 & 5 & 4 & 4 & 4 \\
\hline Geographic distribution & Venezuela & Brazil, Colombia, Peru & $\begin{array}{l}\text { Bolivia, Brazil, French } \\
\text { Guiana, Peru, Suriname }\end{array}$ & Colombia & $\begin{array}{l}\text { Colombia, Costa } \\
\text { Rica, Panama }\end{array}$ & $\begin{array}{l}\text { Brazil, Ecuador, } \\
\text { Peru, Venezuela }\end{array}$ \\
\hline
\end{tabular}

Leaves with numerous secondary and intersecondary veins are also present in Tovomita colombiana L. Marinho and T. nervosa L. Marinho, but these species lack floral buds that are narrowly oblong with cuspidate to slightly rostrate apex (i.e., oblong with rounded apex in T. colombiana and ovoid with rounded apex in T. nervosa). Floral buds with a similar shape are found in T. stylosa Hemsl., but this species has fewer secondary veins (8-9 pairs) and is endemic to Mesoamerica and the Chocoan region. Marinho (2018) pointed out that, due to the larger ovary, pistillate floral buds in species with narrowly oblong floral buds are typically wider than staminate buds in the same species. Although the pistillate individual of T. nebulosa was not described, we expect its pistillate floral buds to be slightly wider than the staminate ones, and the ovary to be 4-carpellate based on the number of pistillode stigmas observed in staminate buds.

Below, we provide an identification key to all species of Tovomita in Venezuela, which is based mostly on vegetative and floral bud characters. The species endemic to Venezuela are indicated with an asterisk $(*)$.

\section{Taxonomic key to species of Tovomita in Venezuela}

1. Petioles $<5 \mathrm{~mm}$ long T. auriculata

1'. Petioles $>6 \mathrm{~mm}$ long .. 2

2. Petioles longitudinally striate 3

2'. Petioles smooth 4

3. Leaves with $<20$ pairs of secondary veins; floral buds spheroid; with c. 25 stamens T. clarkii* 3'. Leaves with > 24 pairs of secondary veins; floral buds ovoid to oblong; with $>40$ stamens T. nervosa*

4. Petioles and inflorescences with lenticels ...... 5

4 '. Petioles and inflorescences without lenticels 6
5. Leaves with 20-30 pairs of secondary veins; inflorescence with primary flower, bracteoles free from each other; ovary 5-carpellate; epicarp smooth T. acutiflora

5'. Leaves with 10-13 pairs of secondary veins; inflorescence lacking primary flower, bracteoles connate, forming calyptra; ovary 4-carpellate; epicarp asperous ... T. albiflora A.C. Sm. 6. Secondary and intersecondary veins similar to each other, intersecondary veins parallel to major secondary ones ...... 7 6'. Intersecondary veins thinner than secondary veins, intersecondary veins basiflexed or reticulating ................. 11

7. Intramarginal vein absent T. fructipendula (Ruiz \& Pav.) Cambess.

7’. Intramarginal vein present ......................................... 8

8. Floral buds nigrescent in sicco ...................................... 9

8'. Floral buds not nigrescent in sicco ............................... 10

9. Leaves with > 30 pairs of secondary veins; stamens c. 50 T. tenuiflora

9'. Leaves with < 23 pairs of secondary veins; stamens c. 20 T. nebulosa

10. Leaf blades broadly elliptic to oblong, secondary veins > 20 pairs, exudate channels inconspicuous; floral buds $>5 \mathrm{~mm}$ long; ovary 5-carpellate........................... T. acutiflora 10'. Leaf blades narrowly elliptic, secondary veins < 14 pairs, exudate channels appearing as continuous blackish lines abaxially; floral buds $<4 \mathrm{~mm}$ long; ovary 4-carpellate T. stergiosii Cuello 11. Intramarginal vein present ....................................... 12 11'. Intramarginal vein absent ............................................ 15 12. Floral buds spheroid, apex rounded; stamens (or staminodes in pistillate flowers) $<20$, subclavate, yellow ............................................ T. guianensis Aubl. 12'. Floral buds ovoid, apex acute or apiculate, rarely rounded; stamens (or staminodes in pistillate flowers) $>20$, terete, white 13 
13. Floral buds 7-11.5 mm long; stigmas not sessile, styles 2-3.5 $\mathrm{mm}$ long T. grata Sandwith

13'. Floral buds 5.5-7 mm long; stigmas sessile 14

14. Staminate inflorescences with up to c. 150 flowers; stamens (or staminodes in pistillate flowers) c. 60, 4.5-6 mm long; epicarp asperous T. turbinata Planch. \& Triana

14'. Staminate inflorescences with up to 9 flowers; stamens (or staminodes in pistillate flowers) 20-35, 3.5-5 mm long; epicarp smooth T. umbellata Benth.

15. Inflorescences one-flowered or a congested dichasium; petals purplish red; ovary 4-carpellate ..... T. atropurpurea Steyerm.* 15'. Inflorescences a lax dichasium or pleiochasium; petals white, cream or yellowish; ovary 5-6-carpellate .............. 16 16. Secondary veins $<7$ pairs ...................................... 17 16'. Secondary veins $>8$ pairs 18

17. Leaf blades with rounded to straight apex; floral buds 7-9 $\mathrm{mm}$ long T. nidiae L. Marinho*

17'. Leaf blades with acuminate apex; floral buds $3.5-5.5 \mathrm{~mm}$ long T. schomburgkii Planch. \& Triana

18. Floral buds $<5 \mathrm{~mm}$ long 19

18 '. Floral buds $>6 \mathrm{~mm}$ long 20

19. Leaf blades purplish-red in sicco, drip tip frequent, secondary veins clearly connecting near the margin; floral buds spheroid

T. gracilipes Planch. \& Triana

19'. Leaf blades greenish to grayish in sicco, drip tip rarely present, secondary veins slightly connecting near the margin; floral buds spheroid to oblong T. schomburgkii

20. Floral buds ovoid. 21

20'. Floral buds oblong 22

21. Floral buds 5.5-7.5 mm long; ovary 4-carpellate; immature fruits spheroid, epicarp rugose... T. macrophylla (Poepp.) Walp. 21'. Floral buds 8-15 mm long; ovary 5-carpellate; immature fruits oblong to ovoid, sometimes falcate, epicarp smooth

T. foldatsii

22. Floral buds with rounded apex; fruit pedicels dilated T. spruceana Planch. \& Triana

22'. Floral buds with acute apex, sometimes mucronulate; fruit pedicels not dilated ............ T. volkeri L. Marinho

\section{ACKNOWLEDGMENTS}

We thank the Conselho Nacional de Desenvolvimento Científico e Tecnológico (CNPq) for awarding a doctoral fellowship to LCM (\# 141561/2015-7), and research productivity fellowships to AMA (\# 312404/2018-2) and PF (\# 310502/2019-5). LCM's visit to The New York Botanical Garden Herbarium (NY) was partially supported by the Coordenação de Aperfeiçoamento de Pessoal de Nível Superior (CAPES, \# 88881.135403/2016-01) and the Harvard
University Herbarium (HUH Travel Grant awarded in 2017). We also thank the curators and administrators of NY who kindly provided the loan and lodging during the visit. We thank Alejandra Vasco (BRIT) for her assistance providing pictures of the isotype.

\section{REFERENCES}

Barros, M.S.; Mariz, G. 1982. Tovomita acutiflora Barros et. G. Mariz espécie nova do Amazonas, Brasil. Acta Amazonica, 12: 291-292.

Berry, P.E.; Huber, O.; Holst, B.K. 1995. Floristic analysis and phytogeography. In: Berry, P.E.; Holst, B.K.; Yatskievych, K. (Eds.). Flora of the Venezuelan Guayana. v.1. Missouri Botanical Garden-Timber Press, St. Louis-Portland, p.161-191.

Cabral, F.N.; Bittrich, V.; Amaral, M.C.E. 2016. Four new species of Caraipa (Calophyllaceae) from the Amazon basin and the Guiana Shield. Phytotaxa, 286: 245-255.

Cabral, F.N.; Bittrich, V.; Amaral, M.C.E. 2018. Five new species of Caraipa (Calophyllaceae) from the Venezuelan Guayana. Systematic Botany, 43: 240-249.

Cuello N.L. 1998. Tovomita. In: Steyermark, J.A.; Berry, P.E.; Holst, K.B. (Eds.). Flora of the Venezuelan Guayana, CaesalpiniaceaeEricaceae, v.4. Missouri Botanical Garden Press, St. Louis, p.313-322.

Cuello N.L. 1999. Two new distinctively large-leaved species of Tovomita (Clusiaceae) from the Venezuelan and Peruvian Amazon region. Novon, 9: 150-152.

Ellis, B.; Daly, D.; Hickey, L.J.; Johnson, K.R.; Mitchell, J.; Wilf, P.; Wing, S.L. 2009. Manual of Leaf Architecture. Cornell University Press, Ithaca, 190p.

Engler, A. 1923. Guttiferae. Beiblatt zu den Botanischen Jahrbüchern 130. In: Engler, A. (Ed.). Botanische Jahrbücher für Systematik, Pflanzengeschichte und Pflanzengeographie. Schweizerbart, Stuttgart, p.1-10.

Frazão, A.; Lohmann, L.G. 2018. A new species of Tanaecium (Bignonieae, Bignoniaceae) from the Brazilian Amazon and its phylogenetic placement. Plant Systematics and Evolution, 304: 1245-1253.

Huamantupa-Chuquimaco, I.; Lima, H.C.; Cardoso, D.B.O.S.; Yuca-Rivas, R.; Ochoa, J.A.; La Vega, D.H. 2019. Tachigali amarumayu (Leguminosae), a new species from terra firme forests of Southwestern Amazonia. Brittonia, 71: 39-48.

Huber, O. 2008. Breve síntesis de los grandes paisajes vegetales de Venezuela. In: Hokche, O.; Berry, P.E.; Huber, O. (Eds.). Nuevo Catálogo de la Flora Vascular de Venezuela. Fundación Instituto Botánico de Venezuela, Caracas, p.41-56.

IUCN. 2012. IUCN Red List categories and criteria: version 3.1, ed.2. (https://www.iucnredlist.org/resources/categories-andcriteria). Accessed on 15 Dec 2019.

Marinho L.C. 2018. Two new species of Tovomita (Clusiaceae) from the Amazonian forest. Brittonia, 70: 405-411.

Marinho, L.C. 2019. Sistemática de Tovomita Aubl. (Clusiaceae) e gêneros relacionados. $\mathrm{PhD}$ thesis, Universidade Estadual de Feira de Santana, Brazil. 260p. 
Marinho L.C.; Gahagen, B.; Amorim, A.M. 2016a. Description of Tovomita clarkii (Clusiaceae), an endemic species from Venezuela. Phytotaxa, 261: 87-91.

Marinho, L.C.; Fiaschi, P.; Gahagen, B.; Santos, F.A.R.; Amorim, A.M. 2016b. Tovomita (Clusiaceae) from the Brazilian Atlantic Forest: taxonomy and utility of leaf venation characters at the species level. Systematic Botany, 41: 758-774.

Marinho, L.C.; Fiaschi, P.; Amorim, A.M. 2019. A gold mine: four more new species of Tovomita (Clusiaceae: Clusieae) from Amazonia. Willdenowia, 49: 343-350.

Melo, E.; Cid Ferreira, C.A.; Gribel, R. 2019. A new species of Coccoloba P. Browne (Polygonaceae) from the Brazilian Amazon with exceptionally large leaves. Acta Amazonica, 49: 324-329.

Nascimento Jr., J.E.; Bittrich, V.; Amaral, M.C.E. 2019. Taxonomic novelties in Clusia (Clusiaceae) from Venezuela. Phytotaxa, 400: 191-202.

Radford, A.E.; Dickison, W.C.; Massey, J.R.; Bell, C.R. 1974. Vascular Plant Systematics. Harper \& Row Publishers, New York, 891p.

Riina, R.; Berry, P.E.; Huber, O.; Michelangeli, F.A. 2019. Vascular plants and bryophytes. In: Rull, V.; Vegas-Vilarrúbia, T.; Huber,
O.; Señaris, C. (Eds.). Biodiversity of Pantepui: The Pristine "Lost World" of the Neotropical Guiana Highlands. Academic Press, London, p.121-147.

Shorthouse, D.P. 2010. SimpleMappr, an online tool to produce publication-quality point maps (https://www.simplemappr.net). Accessed on 03 Oct 2019.

Stern, W.T. 1992. Botanical Latin. History, Grammar, Syntax, Terminology and Vocabulary. Ed. Hafner Publishing Company, New York, 566p.

Thiers, B. 2020. Index Herbariorum: A global directory of public herbaria and associated staff (http://sweetgum.nybg .org/ih/). Accessed on 02 Jan 2020.

Toledo, C.A.P.; Souza, V.C. 2018. Two new species and identification key of Connarus from Brazilian Amazon. Systematic Botany, 43: 754-759.

Vesque, J. 1893. Guttiferae. In: De Candolle, A.; De Candolle, C. (Eds.). Monographic Phanerogamarum 8. Sumptibus G. Masson, Paris, 669p.

RECEIVED: $17 / 02 / 2020$

ACCEPTED: 30/04/2020

ASSOCIATE EDITOR: Ricarda Riina 